DOI: https://doi.org/10.24164/prosiding.v3i1.25

\title{
PROSES DESAIN MUSEUM SITUS PENINGGALAN PERADABAN AUSTRONESIA SEBAGAI MEDIA KONSERVASI DAN TUJUAN WISATA ARKEOLOGI
}

\author{
Museum Design Process for Austronesian Civilization \\ as Conservation Media and Tourism Designation
}

Adli Nadia, Doni Fireza

Universitas Agung Podomoro

Jalan Letjen S. Parman No.28, RT.12/RW.6, Tj. Duren, Kota Jakarta Barat 11470

E-mail: adli.nadia@podomorouniversity.ac.id

\begin{abstract}
There are numerous Archaeological sites which describes the routes of preshistorical human migration in Java. That site has a valuable content in terms of science and tourism potential, but often those two things above runs contradictory. When viewed from science, these historic assets should be preserved and conserved so that traces of previous civilization can be traced continuously, whereas when viewed from tourism, more tourists means more potential damage to historic assets both intentionally and unintentionally, even though the tourist visits have a significant contribution of regional income and all at once, furthermore this income is needed to fund research and assets maintenance on the archeaological sites. This research aims to explore a contextual museum design process that act for preservation and conservation while accommodating tourism. The research method which will be used for this research is a combination of interpretative historical and phenomenological approach with mathematical thinking in architecture to generate most contextual probabilities.
\end{abstract}

Keywords: Site, Subanglarang, Museum, Conservation, Preservation, Subang, West Java, Tourism.

\begin{abstract}
Abstrak
Situs arkeologi yang merupakan salah satu rute migrasi manusia preshistoris berjumlah sangat banyak di pulau Jawa. Situs ini memiliki kandungan yang sangat berharga dari sisi ilmu pengetahuan hingga potensi pariwisata, namun seringkali dua hal diatas berjalan secara bertolak belakang. Apabila ditinjau dari ilmu pengetahuan, aset-aset bersejarah tersebut seharusnya dipreservasi dan dikonservasi agar jejak-jejak peradaban masa lalu dapat terus ditelusuri, sedangkan apabila ditinjau dari pariwisata, semakin banyak wisatawan yang datang artinya potensi rusaknya aset-aset bersejarah baik disengaja maupun tidak disengaja juga akan semakin tinggi, padahal sumbangan pendapatan daerah dari kunjungan wisatawan ini tergolong signifikan bagi pertumbuhan ekonomi kawasan dan dibutuhkan untuk mendanai penelitian dan peratawan situs terkait. Riset ini bertujuan untuk menggali sebuah model proses perancangan museum yang kontekstual dan sekaligus berfungsi untuk preservasi dan konservasi sekaligus mewadahi pariwisata. Metoda penelitian yang akan digunakan untuk penelitian ini adalah gabungan dari interpretasi historis dan fenomenologi serta gabungan dengan metoda berpikir matematis untuk mendapatkan kemungkinan terbaik dalam merespon konteksnya.
\end{abstract}

Kata kunci: Situs, Subanglarang, Museum, Konservasi, Preservasi, Subang, Jawa Barat, Pariwisata. 


\section{PENDAHULUAN}

$\mathrm{P}$ enggalian situs arkeologi guna mencari asal usul budaya dan peradaban manusia seringkali bertolak belakang dengan kebutuhan mempreservasi elemen-elemen fisik situs. Kondisi tersebut akan bertambah kompleks ketika situs bersejarah tersebut sudah menjadi obyek pariwisata yang berdampak pada pendapatan daerah. Asetaset kesejarahan tersebut menjadi rentan atas pengerusakan baik disengaja maupun tidak disengaja padahal aset-aset tersebut merupakan sumber pengetahuan yang bernilai sangat tinggi sekeligus harus dapat dinikmati oleh publik.

Pada studi kasus Subanglarang - Jawa Barat, elemen-elemen fisik kesejarahan juga mendapatkan ancaman yang sama dari penggalian situs arkeologi secara liar dan banyaknya jumlah wisatawan yang berkunjung. Hal ini disebabkan oleh berkumpulnya 2 situs sejarah di satu lokasi. Situs bersejarah pertama adalah kerangka manusia yang diduga berusia 45 SM dan merupakan bagian dari manusia Austronesia, sedangkan situs kedua adalah Maqom atau petilasan Nay Subang Larang yang merupakan salah satu istri Prabu Siliwangi dan leluhur dari Sunan Gunung Jati.

Kedua situs sejarah tersebut memiliki rentang waktu yang cukup jauh, yaitu $+/-$ 45SM untuk kerangka manusia dan +/1400M untuk Nay Subang Larang, sehingga secara kesejarahan kerangka manusia purba tentu memiliki nilai yang lebih bersejarah sebab terkait dengan asal usul peradaban manusia di pulau Jawa. Namun hikayat Nay Subang Larang ternyata lebih memikat datangnya pengunjung, bahkan menurut pengelola situs, sejak 2014 (saat dibukanya situs) setidaknya 1000 pengunjung mendatangi situs ini tiap bulannya.
Interaksi antara situs kerangka manusia dan situs Nay Subang Larang merupakan fenomena yang sangat menarik sebab selain mengandung informasi migrasi manusia prehistoris pada era Pleistocene akhir yang bernilai tinggi, Situs Nay Subang Larang sekaligus menjadi aset pariwisata yang potensial dan menghasilkan wisata rohani dan budaya. Dalam rangka mewadahi beragam kegiatan utama di atas secara bersamaan dan mampu bersinergi maka dibutuhkan sebuah fasilitas dengan strategi perancangan yang tepat.

Menurut Icomos (International Council of Museums, 2017), museum adalah sebuah tipologi yang dianggap paling sesuai pada kasus ini. Hal itu didasari oleh studi beberapa preseden misalnya International Center for Cave Art, Perancis; Pompeii archaeological site, Italy; MuséoParc Alésia archaeological site, Côte-d'Or, France. Di sini, museum berfungsi sekaligus untuk mempreservasi benda-benda bersejarah sekaligus media representatif bagi para wisatawan. Selain itu, museum juga berfungsi sebagai perimeter situs yang masih dalam tahap eksplorasi agar tidak mengalami kontaminasi dari wisatawan. Dengan begitu, upaya konservasi situs sekaligus sebagai sarana edukasi dapat diwujudkan dengan direncanakannya sebuah museum.

Dari latar belakang di atas, permasalahan yang dapat dirumuskan adalah:

1. Bagaimana tipologi desain museum sebagai alat konservasi arkeologi yang sesuai dengan karakteristik Subanglarang?

2. Bagaimana strategi dan proses perancangan museum tersebut dengan mempertimbangkan sense of place dan karakteristik lokasi Situs Subanglarang? 


\section{KAJIAN LITERATUR}

Menurut Peraturan Pemerintah No19 tahun 1995, museum berperan penuh sebagai wadah untuk menyimpan, merawat, memanfaatkan serta berkomunitas dalam rangka melestarikan dan melindungi kekayaan budaya bangsa. Namun demikian, fungsi museum tidak hanya terbatas pada perlindungan dan pelestarian benda pusaka namun kawasan, lingkungan dan alam yang mengandung nilai-nilai sejarah tinggi. Pada awal perkembangan museum di era arsitektur modern, tipologi atau jenis Museum sangat erat kaitannya dengan kepengelolaannya, hal ini di utarakan oleh Wise. C dan Erdos. A (Wise \& Erdos, 1975). Menurut mereka, kepengelolaan museum dibedakan ke dua arah, yaitu berorientasi ke koleksi pusakanya atau berorientasi pada pengunjung, namun demikian seiring dengan berjalannya waktu, kedua hal tersebut seringkali berjalan beriringan sebab berkaitan erat dengan semakin luasnya manfaat museum saat ini.

Pada tahun 2003, Ioannidis (Ioannidis et al., 2003)menggambarkan pergeseran konsep museum yang tadinya hanya bermanfaat untuk konservasi, pameran dan penelitian menjadi wadah ilmu pengetahuan dan berbagi informasi yang interaktif. Perubahan mendasar pada konsep museum ini terletak pada inovasi penyajian benda koleksi yang tidak lagi statis. Seiring dengan waktu, muncul beberapa inovasi terkait museum antara lain: (1) Konsep Penyajian Benda-benda Pusaka Pada Museum; (2) Olah ruang dan meredefinisi bahasa ruang pada museum; (3) Perkembangan tipologi museum.

Selain tipologi, museum memiliki tipe-tipe penyajian yang berkaitan erat konservasi, perencanaan dan manajemennya (Mosler, 2006). Berikut ini adalah beberapa tipe penyajian pada museum yang sering ditemukan: (1) Museum yang menyajikan model-model interpretasi (interpretative museum); (2) Museum yang menyajikan langsung situsnya pada publik (purist museum); (3) Museum yang menyajikan model-model imajiner; (4) Museum yang menyajikan rangkaian cerita atau jaringan arkeologi; (5) Museum yang menyajikan situs di tengah-tengah ruang publik kota.

\section{Studi Preseden}

Dalam upaya memahami lebih jauh bagaimana tipologi dan jenis penyajian ini diterapkan, dilakukan studi pada beberapa preseden (Bianchini, 2017), antara lain: (1) Pompeii Archeological site, Naples, Italy; (2) Herculaneum archaelogical site, Naples Italy; (3) International Center for Cave Art, Montignac, France; (4) Aguntum Museum, Austrian Tyrol; (5) MuseoParc Alesia archaelogial site, Cote-d'Or;

Dari ke lima telaah preseden tersebut, dapat disimpulkan bahwa jenis penyajian (interpretative, purist, imajiner, dan lainlain) bukanlah pilihan melainkan strategi agar tujuan museum sebagai wadah untuk edukasi dan preservasi dapat tercapai (Matero, 2006). Strategi dan kombinasi penyajian tersebut mempertimbangkan 4 hal (Matero, 2006), yaitu:

1. Ukuran kawasan preservasi (besar atau kecilnya kawasan)

2. Ketersediaan dan kualitas artefak atau benda-benda bersejarah pada situs

3. Tingkat konservasi dan proteksi pada artefak dan benda-benda kesejarahan.

4. Keterikatan antara situs dan kondisi lansekapnya dalam rangka penggalian makna. 


\section{Temuan Lapangan}

\section{- Analisa Nilai Signifikansi Situs}

Obyek budaya dan kesejarahan pada situs subang larang terbagi menjadi 2 yaitu napak tilas Nyai Subang Larang yang merupakan istri dari Raden Pamanah Rasa (Prabu Siliwangi pada periode $1400 \mathrm{M}$ ) dan Nenek dari Sunan Gunung Jati (Syarif Hidayatulloh), sedangkan obyek kesejarahan yang kedua adalah ditemukannya kerangka manusia yang berasal dari tahun 45 sebelum Masehi oleh seorang arkeolog Universita Padjajaran Dr. Lutfi Yondri.

\section{Maqom Nyai Subang Larang}

Menurut kitab CPCN, Nyai Subang Larang adalah anak dari seorang syahbandar (panglima sebuah pelabuhan) di kawasan utara Jawa Barat yang bernama Pelabuhan Muara Jati. Nyai Subang larang lalu dipinang oleh oleh seorang putra mahkota kerajaan Pakuan (saat ini bernama kawasan Bogor) yang bernama Raden Pamanah Rasa. Seiring dengan berjalannya waktu, Raden Pamanah Rasa lalu diangkat menjadi Raja Pakuan yang bergelar Prabu Siliwangi.

Nyai Larasantang kemudian memiliki 2 anak yang bernama Syarif Hidayatullah yang kemudian dikenal sebagai Sunan Gunungjati dan Rajasangara kemudian dikenal dengan nama Kiansantang (lebih dikenal sebagai satria perang kerajaan Pakuan).

Nyai Subang Larang pun akhirnya dikenang sebagai Ibu Suri kerajaan Pakuan yang berpengaruh pada perkembangan islam di Pulau Jawa dan tumbuhnya kesultanan di Pesisir Jawa.
Nilai Menurut wawancara dengan Bapak

Spiri- Sonjaya selaku ketua yayasan dan tual pengelola situs tersebut, kegiatan wisata rohani, para peziarah yang datang menghabiskan waktu cukup panjang disini, kegiatan yang mereka lakukan pun sangat beragam, mulai dari sholat, berzikir, hingga menggelar pengajian semalam suntuk. Selain untuk berziarah, situs ini juga cukup sering di jadikan wadah berkegiatan budayawan sunda, misalnya saresehan, pementasan kesenian wayang golek, Sisingaan, Gembyung, Tayub, Tutunggulan dan tarian tradisional, pembacaan nasehat yang berupa puisi.
Nilai

Sosial

dan

Artistik

Artistik
Secara nilai Sosial, berkumpulnya manusia di situs ini adalah dampak dari tingginya aktivitas kerohanian akibat nilai historis dan spiritual yang berkaitan erat dengan agama, kepercayaan, ritual dan kekaguman pada asal usul kerajaan Sunda. Fenomena berkumpulnya manusia ini lalu ditanggapi oleh penduduk sekitar melalui pembuatan gubukgubuk penjaja makanan, jasa ojek, mikrolet dan pasar malam.

N i 1 a i Secara geografis, situs Subang Alami Larang terletak di pinggiran sungai kecil dan dibatasi oleh hutan dan sawah, namun apakah kondisi geografis ini sama di masa lalu atau tidak belum bisa dibuktikan. Hutan jati yang saat ini ditanam di dalam situs adalah hasil penanaman Pak Sonjaya sebagai penaung dari $\mathrm{dr}$ sinar matahari. Meskipun demikian, posisi maqom terletak di dataran yang tertinggi apabila dibandingkan dengan sekitarnya. 


\section{Manusia Austronesia}

\begin{tabular}{ll}
\hline Nilai & Menurut kantor berita www.bbc. \\
Sejarah & com, upaya penggalian pertama \\
& kali dilakukan pada tahun 2016 \\
& dan dipimpin oleh arkeolog senior \\
& Jawa Barat, Lutfi Yondri. Menurut \\
& paparan beliau, 3 kerangka manusia \\
& yang ditemukan ini berumur 45 \\
& SM (berdasarkan penanggalan \\
& karbon). Selama proses penggalian \\
& ditemukan beragam benda-benda \\
& kesejarahan misalnya senjata dari \\
& logam, manik-manik, pecahan atau \\
& fragmen tembikar, taring babi, dan \\
& sisa moluska laut. \\
& Semenjak ditemukannya kerangka \\
& tersebut, situs Subang Larang saat \\
& ini berstatus sebagai inventarisasi \\
& situs cagar budaya Provinsi \\
& Jawa Barat dan diharapkan dapat \\
& segera mendapatkan status cagar \\
budaya agar bisa mendapat upaya \\
konservasi yang layak.
\end{tabular}

persebaran Islam di Jawa Barat. Sedangkan pada situs kerangka manusia austronesia, tipe penyajian yang tepat adalah purist dan pengunjung diajak untuk mengalami secara langsung hasil penggalian kerangka Austronesia.

Untuk menceritakan legenda raktyat tersebut, Situs Subang larang harus ditata seiring dengan proses ritualnya. Berdasarkan pengamatan, rangkaian ritual dan aktivitas pengunjung terbagi menjadi 2 tipe, yaitu peziarah yang datang dengan durasi pendek (+/- 2 - 3 Jam) dan peziarah yang datang dengan durasi panjang (+/- $8-10$ Jam). Berikut ini adalah diagram aktivitas kedua peziarah:

Dari hasil analisa di atas, jenis penyajian yang cocok untuk konservasi kedua jenis situs jenis ini adalah Purist dan interpretasi (Mosler, 2006) dalam rangka membangun imajinasi. Namun demikian, museum purist antara situs Austronesia dan maqom Subang Larang harus dipisah secara berjauhan dan disertai dengan elemen fisik sebab berpotensi saling mengganggu atau merusak akibat berkumpulnya pengunjung secara berlebihan. Sedangkan museum interpretasi dapat saja diletakkan berdekatan namun tetap memiliki batas yang jelas agar informasi dan data yang ditampilkan tidak tercampur sehingga membingungkan.

\section{- Analisa Penentuan Zonasi}

\section{- Analisa Pemilihan Model Penyajian Situs}

Sesuai dengan analisa pada kandungan nilai kesejarahan di atas, konservasi pada maqom akan menitik beratkan pada keutuhan cerita atau legenda rakyat dimana Nyai Subang Larang adalah bagian dari tumbuh kembang kerajaan Sunda dan awal mula

Zonasi situs merupakan hal yang sifatnya wajib dari sisi proteksi dan pengelolaan menurut ICOMOS (Australia ICOMOS, 2013). Zonasi yang umum dikenal adalah zona inti (core zone) dan zona perlindungan (buffer zone).

Berdasarkan wawancara pada pemilik yayasan sekaligus pengelola situs ini, zonasi 
yang mereka tetapkan ternyata bertumpu pada unsur-unsur fisik lingkungan misalnya: garis batas sungai, garis batas persawahan, garis batas parit dan garis batas pepohonan. Berikut ini adalah gambaran Zonasi situs Subang Larang menurut pengelola Situs seperti tampak pada Gambar 3.
Pembagian zonasi di atas, menurut pengelola, dianggap paling ideal meskipun berpotensi terjadi pengumpulan pengunjung di satu titik pada satu waktu yang bersamaan yaitu di Zona 1. Pemusatan ini diakibatkan oleh berkumpulnya seluruh aktivitas dan bangunan fasilitas pendukung pada zona

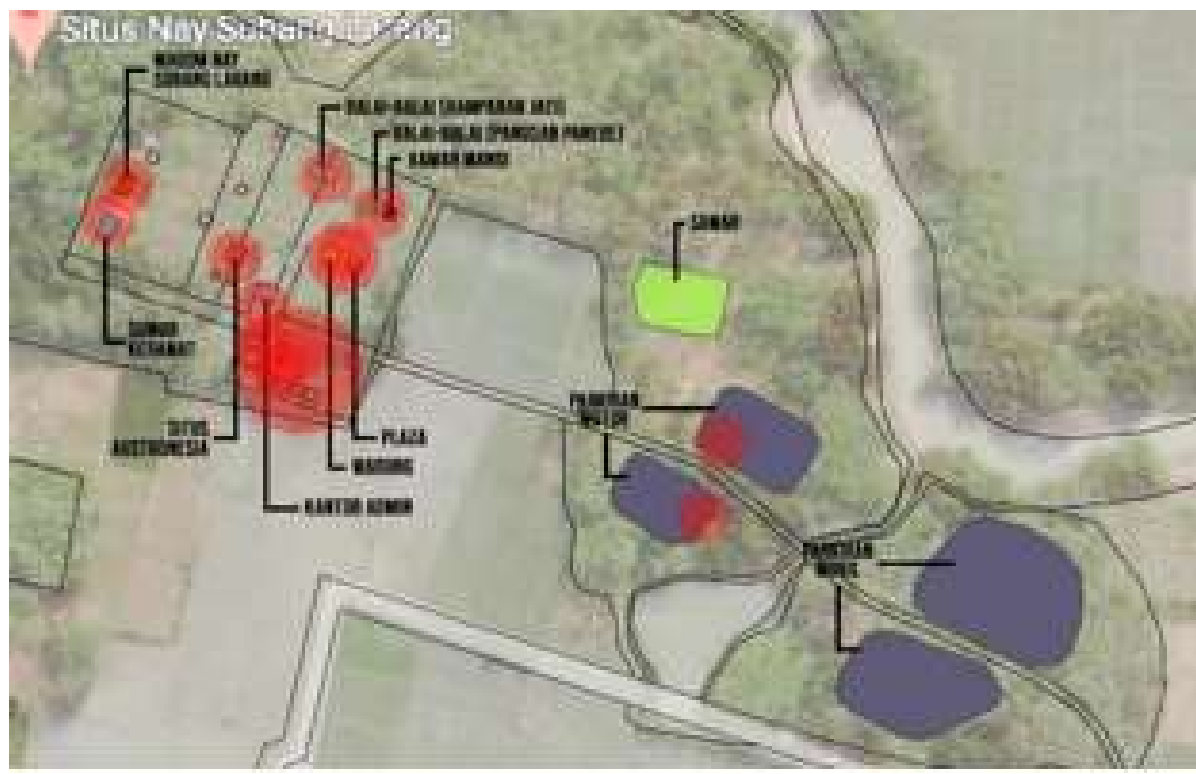

Gambar 1. Persebaran Peziarah di kawasan situs (Sumber: Visualisasi peneliti, tahun 2019).

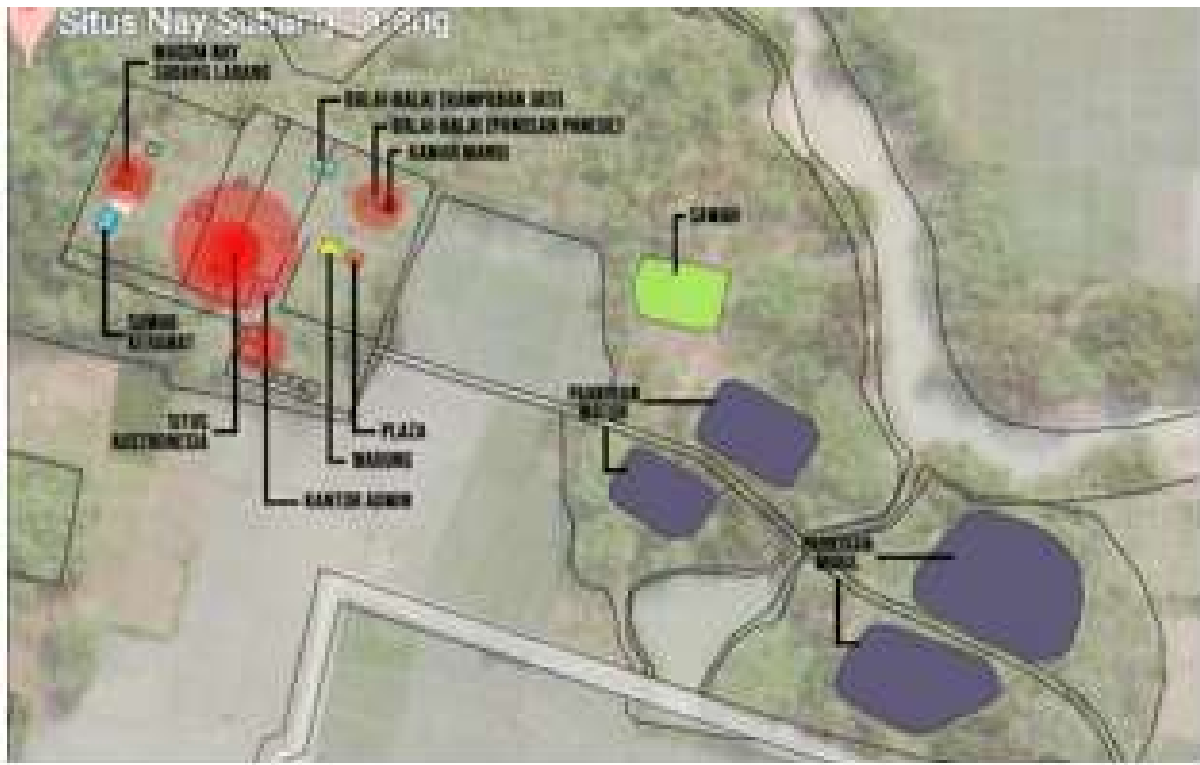

Gambar 2. Persebaran Peneliti dan anak sekolah di kawasan situs (Sumber: Visualisasi peneliti, tahun 2019). 


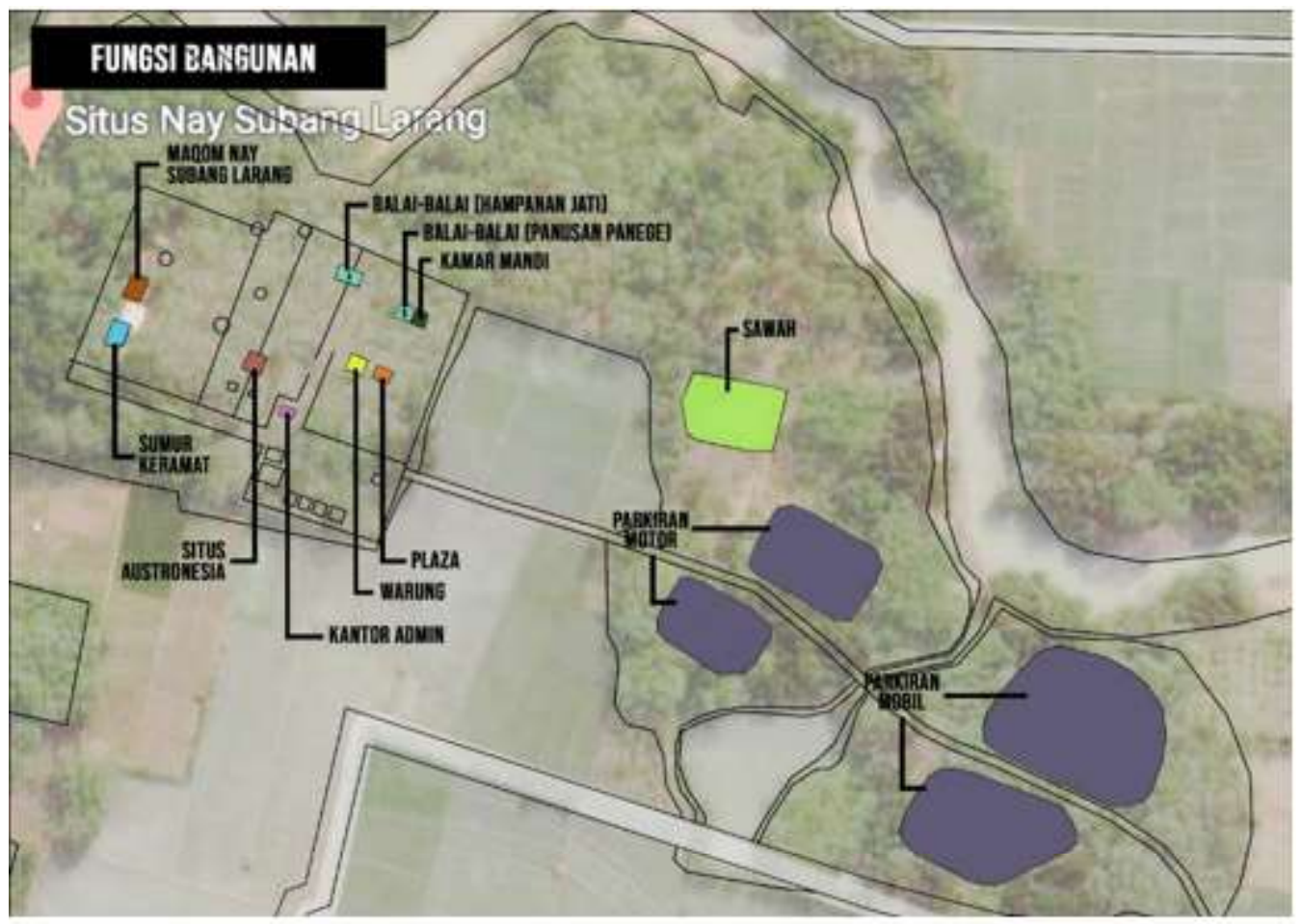

Gambar 3. Zonasi Situs Subanglarang (Sumber: Visualisasi peneliti).

ini. Meskipun jarang terjadi, penumpukan ini diperburuk dengan adanya kegiatan kebudayaan sunda yang dihadiri oleh ratusan warga Subang. Pada saat aktivitas ini terjadi, potensi perusakan situs bersejarahpun meningkat.

\section{PEMBAHASAN}

\section{Proses Perancangan}

Tahapan awal dari sebuah proses perancangan setelah seluruh nilai signifikansi situs dikumpulkan adalah penggalian jenis tipologi, temuan lapangan yang kemudian dapat disimpulkan kriteria perancangan museum Subanglarang sebagai media konservasi situs arkeologi sebagai berikut:

1. Perencanaan museum sebagai wadah konservasi, edukasi dan wisata rohani di situs ini harus dapat memunculkan karakter budayanya, terutama nilai historis dan nilai spiritualnya.
2. Perencanaan museum juga harus dapat merespon konteks dan perekonomian di wilayah tersebut.

3. Zonasi situs ini terbagi ke 3 bagian. 3 zonasi ini ditentukan oleh hasil wawancara terkait konservasi dan potensi kerusakan akibat tingginya jumlah pengunjung yang datang.

4. Bentuk penyajian yang paling cocok untuk diterapkan pada museum ini adalah dominan purist-interpretasi dalam rangka penyamaan persepsi pandangan.

5. Perencanaan museum tetap dalam koridor preservasi, pendidikan, promosi kebudayaan, partisipasi masyarakat sekitar yang sesuai dengan ICOM.

6. Konsep museum yang akan dipakai akan terbagi menjadi 2, konsep imajiner dengan bantuan teknologi dan audio visual dan konsep naratif untuk 
menjelaskan sejarah Nyai Subang Larang.

7. Museum ini nantinya lebih berfungsi untuk mendukung aktivitas publik yang terjadi di sekitar situs sekaligus museum sebagai wadah konservasi atau perlindungan.

Tabel 1. Analisa peletakan museum

\begin{tabular}{|c|c|c|c|c|c|c|}
\hline & \multicolumn{6}{|c|}{ Dekat dengan } \\
\hline & & $\begin{array}{l}\text { Titik Pencrahan } \\
\text { Atstromesia } \\
\text { (mona inti) } \\
\text { A }\end{array}$ & $\begin{array}{l}\text { Maqom Nay } \\
\text { Subaenlarats } \\
\text { (Zona inti) } \\
\text { B }\end{array}$ & $\begin{array}{l}\text { Warang dan Aals } \\
\text { sebagai pusat } \\
\text { perbumpalan } \\
\text { pongunjung } \\
\text { C }\end{array}$ & $\begin{array}{c}\text { Zona } 2 \\
\text { (parkar motos) } \\
\text { D }\end{array}$ & $\begin{array}{c}\text { Zeas } 3 \\
\text { (parkir mobil) } \\
\text { E }\end{array}$ \\
\hline & $\begin{array}{l}\text { Intik } \\
\text { Pentralian } \\
\text { Austronenia } \\
\text { (zona inti) } \\
01\end{array}$ & & 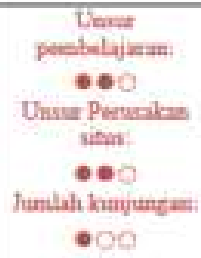 & 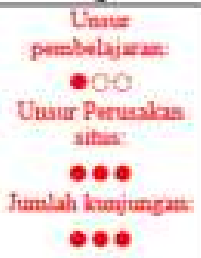 & 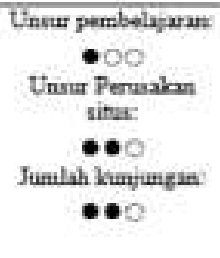 & 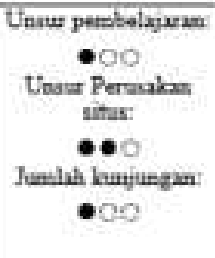 \\
\hline & $\begin{array}{l}\text { Maquen } \\
\text { Nay } \\
\text { Subanglara } \\
\text { es } \\
\text { (Zoma int) } \\
\text { 02 }\end{array}$ & 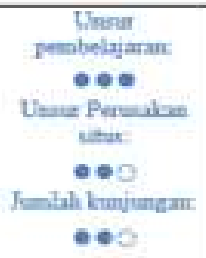 & & 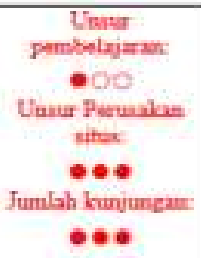 & 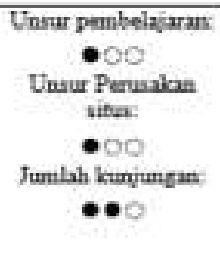 & 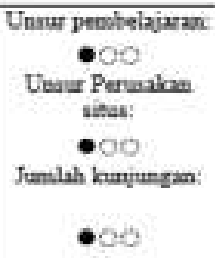 \\
\hline 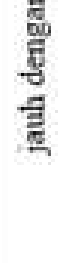 & 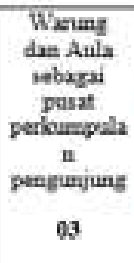 & 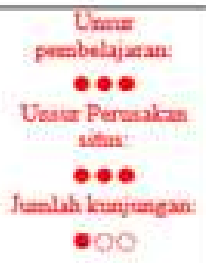 & 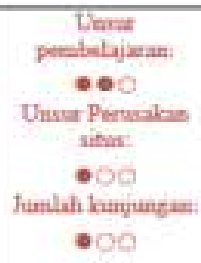 & & 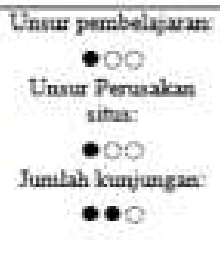 & 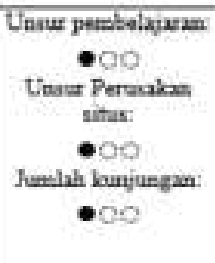 \\
\hline & $\begin{array}{c}\text { Zoma } 2 \\
\text { (parkir } \\
\text { enotor) } \\
04\end{array}$ & 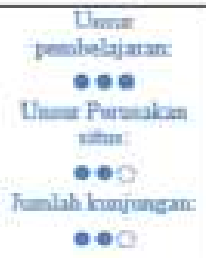 & 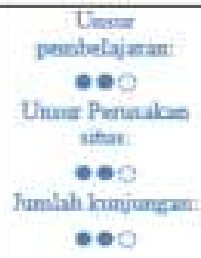 & 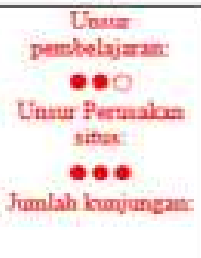 & & $\begin{array}{l}\text { Unsur perbbelajaran: } \\
\text { Couur Perasakon } \\
\text { vitas: } \\
\text { fumlah kunjungan: }\end{array}$ \\
\hline & $\begin{array}{l}\text { Zonia 3 } \\
\text { (parkir } \\
\text { mobili) } \\
06\end{array}$ & 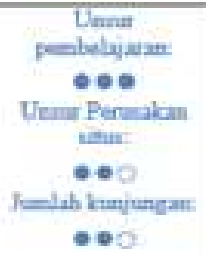 & 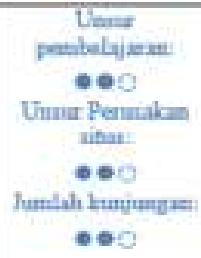 & 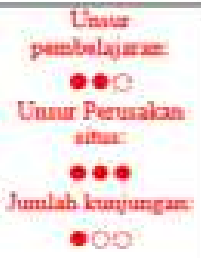 & 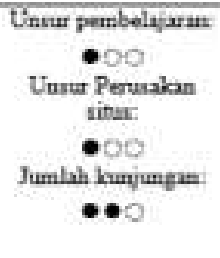 & \\
\hline
\end{tabular}

Sumber: Visualisasi peneliti.

Keterangan:

- : : rendah

$\bullet \bullet$ : menengah

$\bullet \bullet \bullet$ : tinggi 
Proses perancangan selanjutnya adalah menentukan titik peletakan museum yang merupakan kompromi dari posisi dan letak beberapa elemen situs yaitu: titik penggalian austronesia, maqom Nay Subanglarang, aktivitas dan ritual pengunjung, peletakkan bangunan fasilitas pendukung (warung dan aula) serta tempat parkir motor atau mobil. Berikut ini adalah analisa dan prediksi kekurangan dan kelebihan apabila peletakkan museum berkompromi dengan elemen-elemen di atas.

Dari tabel 1, pemilihan lokasi akan didasarkan pada prediksi secara umum dengan mengikuti algoritma berikut ini: (1) Museum tidak akan diletakkan pada area yang memiliki unsur pembelajaran rendah (bintang 1). (2) Museum tidak akan diletakkan pada area yang potensi perusakan situsnya tinggi (bintang 3). (3) Museum diprioritaskan untuk diletakkan pada area yang potensi pengunjungnya ramai (bintang 2).

Dengan demikian, dapat dipetakan beberapa posisimuseumyang optimal sebagai wadah pembelajaran dan penyimpanan artefak namun memiliki dampak minimal terhadap perusakan situs bersejarah serta terletak di titik yang potensial menjaring keramaian atau wisatawan. Posisi terbaik ditandai dengan warna biru, sedangkan warna orange akan berpotensi cukup baik namun kurang optimal, sedangkan warna merah merupakan posisi yang harus dihindari. Meskipun demikian, posisi terbaik (warna biru) tetap harus dirangkai kembali dengan memindahkan bangunan fasilitas pendukung agar tingkat keberfungsian dan dampaknya dapat lebih maksimal.

\section{SIMPULAN}

Dengan demikian proses perancangan museum pada situs Nyai Subanglarang memiliki tatanan (algoritma) sebagai berikut: Pertama-tama, tipologi museum (purist atau interpretative atau kombinasi keduanya) ditentukan terlebih dahulu untuk menentukan bagaimana museum berinteraksi dengan elemen-elemen sosial, nilai dan budaya pada konteksnya. Setelah tipologi dan elemen-elemen inti tersebut ditentukan, maka perumusan kriteria perancangan dapat dilakukan dengan pengamatan lapangan, penggalian data primer pada tapak dan disertai dengan studi literatur yang berujung pada pengumpulan nilai-nilai signifikansi. Tahapan selanjutnya adalah penentuan zonasi (zona inti dan pelindung) dan titik pendirian museum yang ditentukan secara politis /kompromi antara 3 kepentingan utama pengguna (peziarah, pegiat kebudayaan lokal serta peneliti atau siswa sekolah) dengan titik-titik pusat berkegiatan mereka.

Dikarenakan sifat penentuan lokasi ini politis, sehingga tidak mudah untuk menggabungkan 3 pengguna di atas sebab sifat, periaku dan ritualnya yang berbedabeda. Dengan demikian dibutuhkan sebuah strategi pembobotan yang bertujuan untuk mempersempit kemungkinan lokasi museum tersebut. Hasil dari pengerucutan ini lalu membutuhkan satu tahapan akhir yaitu simulasi perancangan yang kemudian diverifikasi pada pengelola maupun pihak terkait lainnya agar tujuan keberfungsian museum dapat tercapai dengan dampak positif secara sosial maupun ekonomi pada masyarakat.

\section{DAFTAR PUSTAKA}

Australia ICOMOS. (2013). The Australia ICOMOS Charter for Places of Cultural Significance, 2013. The Burra Charter. https://doi. org/363,690994 
Bianchini, R. (2017). Museo Parc Alesia archaeological site. https:// www.inexhibit.com/mymuseum/ museoparc-alesia-bourgogne/

International Council of Museums. (2017). iCom Code of ethiCsfor museums. Maison de l'UNESCO. https:// i com.museum/w p-content/ uploads/2018/07/ICOM-code-Enweb.pdf

Matero, F. (2006). Making Archaeological Sites: Conservation as Interpretation of an Excavated Past. In Of the Past, for the Future: Integrating Archaeology and Conservation.

Mosler, A. S. (2006). Landscape Architecture On Archaeological Sites Establishing landscape design principles for archaeological sites by means of examples from West. Fakultät Für Architektur.

Wise, C., \& Erdos, A. (1975). Museum Architecture, Museum, XXVI (C. Wise (ed.)). UNESCO. https://unesdoc. unesco.org/ark:/48223/pf0000127357

\section{HASIL DISKUSI}

\section{Pertanyaan}

\section{Retno Purwanti (Balai Arkeologi Sumatera Selatan)}

Mengapa harus dibuat museum di situ?

\section{Jawaban}

1. Terkait dengan zonasi, jadi kita pun bertanya mengenai hal tersebut kepada narasumber salah satunya Pak Luthfi karena menurut arkeolog sendiri ada zona yang paling aman untuk museum. Kajian tentang zonasinya memang belum ada. Memang perlu ada riset di awal, tapi kita bukan arkeolog dan kita juga tidak menguasai hal tersebut jadi kita coba langsung lari ke model museumnya.
Lalu kenapa Nyai Subang Larang digabung dengan Austronesinya, itu karena inisiatif kami karena biasanya pengunjung datang untuk melihat situs Nyai Subang Larangnya bukan karena fosil manusia austronesianya. Kita juga baru tau rangka itu jadi barulah anakanak SD yang mempelajari manusia prasejarah mereka bisa melihat secara langsung. Sayangnya untuk pengunjung yang jumlahnya mungkin mencapai ribuan itu lebih datang untuk melihat Nyai Subang Larangnya. Agak sulit untuk memilih salah satu ini karena dari sisi keuangan bisa saling menghidupi. Selain itu terkait dengan artefak yang diletaknya in situ mungkin terkait dengan bagannya Mas Erwin mengenai museum yang terbagi menjadi museum tradisional, modern, pascamodern. Kondisi saat ini museum kita lebih kepada museum tradisional karena sifatnya satu arah. Dengan adanya konsep artefak yang in situ diharapkan pengunjung dapat lebih dekat dengan artefaknya. Oleh sebab itu kami berusaha bergeser dari tradisional ke modern/ pascamodern supaya interpretasi anakanak terbangkitkan dan harapannya untuk media dan ruang edukasi tetapi jika memang ada zonasi yang melarang, kita akan pindahkan.

\section{Saran}

1. Penentuan Zonasi sebaiknya dilakukan melalui riset tersendiri yang lebih mendalam.

2. Penelitian ini dapat dilanjutkan dengan tahapan simulasi dan verifikasi pada masyarakat, pengelola, serta pemerintah daerah setempat. 